\title{
Perbedaan Kecepatan Berjalan Penggunaan Rigid Medial Arch Support dengan Flexible Medial Arch Support pada Penderita Flat Foot
}

\author{
Atika Febri Anggriani $^{1 *}$, Yopi Harwinanda Ardesa ${ }^{2}$, Prasetyo Catur Utomo ${ }^{3}$ \\ 1,2,3 Poltekkes Kemenkes Surakarta Jurusan Ortotik Prostetik \\ Email: atikaanggriani07@gmail.com
}

\begin{abstract}
Background: Flat foot is a clinical orthopedic condition that occurs when the medial longitudinal arc does not appear from birth, this condition can cause complaints of fatigue and restrict walking activities. Handling of flat foot in the prosthetic orthotic field is by the use of medial arch support that can be made with various types of designs and materials. In terms of orthosis type material can be either rigid medial arch support and flexible medial arch support that can be used to correct flatfoot conditions. The purpose of this study was to determine whether there were differences in walking speed with the use of rigid medial arch support and flexible medial arch support in patients with flat foot. Methods: This type of research is Observational with Cross Sectional design. The samples used were children aged 8-12 years totaling 20 samples of boys and girls, grades 4 through 6 Elementary School, with body weights of 26-60 $\mathrm{kg}$, and height of 124-150 cm. The results of calculating the average walking speed using rigid medial arch support is $0.69 \mathrm{~m} / \mathrm{s}$ and the average result of walking speed calculation using flexible medial arch support is $0.78 \mathrm{~m} / \mathrm{s}$. Results: The results of Shapiro Wilk data normality $(N=20)$ show that the data is not normally distributed. So by using the non parametric test (Wilcoxon test) obtained $P=0,000(P$ <0.05). Conslusion: ConFrom the test results it can be concluded that there are differences in the speed of walking using rigid medial arch support with flexible medial arch support in patients with flat foot. This is because the use of medial arch support with flexible material can be used to support the arch to stay awake. While the use of rigid medial arch support is stiffer and less able to adjust foot movements, especially when walking.
\end{abstract}

Keywords: rigid medial arch support, flexible medial arch support, walking speed, flat foot

\section{PENDAHULUAN}

Flat foot adalah sebuah kondisi orthopedic klinis yang terjadi ketika arcus longitudinal medial tidak muncul sejak lahir dan area tersebut tertimbun jaringan lemak (Sahabuddin, 2016). Semua anak terlahir dengan kondisi flat foot, namun secara perlahan seiring dengan bertambahnya usia pada masa kanak-kanak, kondisi lengkung medial longitudinal telapak kaki tersebut akan mulai terbentuk, yang mana biasanya terbentuk pada usia sekitar 5 atau 6 tahun (Mortazavi, 2007).

Perlu kita ketahui bahwa jumlah populasi anak di dunia yang menderita kelainan flat foot sekitar $20 \%$ hingga $30 \%$ anak (Evans, 2008). Dari observasi pendahuluan yang telah dilakukan oleh
Prasetyo Catur Utomo, Dwi Setyawan, Muhammad Syaifuddin (2017) pada siswa kelas 3 - 6 SDN 1 Gagak Sipat sejumlah 148 siswa yang terdiri dari 34 siswa kelas 3, 37 siswa kelas 4, 38 siswa kelas 5, dan 39 siswa kelas 6 diperoleh hasil bahwa $57(38,5 \%)$ siswa menderita flat foot.

Kondisi flat foot ini dapat mempengaruhi gait parameter pada penderita karena bentuk tapak kaki yang ceper/flat tanpa adanya lengkung di bagian medial longitudinal arcusnya kurang mampu berfungsi sebagai sistem pengungkit yang kaku/rigid untuk mengungkit tubuh pada saat kaki akan meninggalkan pijakan pada saat berjalan (fase push off) (Idris, 2010), sehingga dapat menimbulkan keluhan mudah lelah 
dan membatasi aktifitas berjalan pada penderitanya (Lutfie, 2007).

Penanganan flat foot dilakukan dengan beberapa cara yaitu : (1) melakukan program penguatan otot (strengthening), (2) penggunaan orthosis (insole atau medial arch support), (3) obat anti inflamasi, (4) modifikasi aktivitas, (5) penurunan berat badan, dan (6) intervensi bedah atau operasi (Sahabuddin, 2016). penanganan flat foot dilakukan dengan penggunaan medial arch support. Medial arch support digunakan untuk dapat mengontrol penyelarasan, fungsi tungkai bawah, serta digunakan untuk membatasi gerakan pronasi berlebih. Orthosis ini tidak hanya bekerja dengan prinsip menopang arcus pedis pada foot, tetapi juga memperbaiki kembali struktur kaki untuk mencegah kelainan yang terjadi pada pada tulang, otot, tendon, serta kelelahan ligamen (Santoso, 2011). Medial arch support dapat dibuat dengan berbagai jenis desain dan material. Fungsi, rigidity, dan pilihan material saling berhubungan. Penentuan fungsi yang diinginkan akan membantu ortotist untuk menentukan rigidity dan material yang dibutuhkan dalam pembuatan alat tersebut (Sue Weber, 2004). Dari segi
Pada bidang ortotik prostetik

material jenis orthosis ini dapat berupa rigid medial arch support yang dibuat dengan bahan plastic polyethylene (PE) dan flexible medial arch support yang dibuat dengan bahan EVA.

Penelitian ini dilakukan dengan tujuan untuk mengetahui perbedaan kecepatan berjalan pada penderita flat foot dengan menggunakan rigid medial arch support dan dengan menggunakan flexible medial arch support.

\section{METODE PENELITIAN}

Jenis penelitian yang digunakan adalah penelitian Observasional dengan menggunakan desain Cross Sectional. Subyek yang digunakan adalah anak usia 8-12 tahun kelas 4-6 sekolah dasar yang mengalami flatfoot di SDN 1 Gagak Sipat, Ngemplak, Boyolali, yang telah dibuktikan dengan footprint test oleh peneliti sebelumnya untuk mengetahui kondisi flat foot atau tidak. Subjek yang dilakukan intervensi telah ditentukan kriteria inklusi dan eksklusinya. Jumlah subyek penelitian sebanyak 20 orang dengan jenis kelamin laki-laki sejumlah 12 anak dan jenis kelamin perempuan sejumlah 8 anak.

\section{HASIL PENELITIAN}

Tabel 1. Hasil uji normalitas data dengan Shapiro-wilk $(\mathrm{N}=20)$

\begin{tabular}{lcl}
\hline \multicolumn{1}{c}{ Perlakuan } & Sig. Shapiro-Wilk & Keterangan \\
\hline Rigid medial arch support & 0,038 & Tidak normal \\
Flexible medial arch support & 0,037 & Tidak normal \\
\hline
\end{tabular}

Berdasarkan tabel 1 diatas, uji nilai $\mathrm{P}=0,038$, dan pada Flexible medial normalitas dilakukan dengan arch support menunjukkan nilai $\mathrm{P}=0,037$. menggunakan Shapiro-wilk karena jumlah Dari hasil uji normalitas menunjukan nilai subjek penelitian < 50. Hasil uji $\mathrm{P}>0,05$, sehingga artinya semua data normalitas pada anak yang menggunakan terdistribusi tidak normal. 
Tabel 2. Hasil Analisa Data dengan Wilcoxon Signed Ranks Test

\begin{tabular}{lccc}
\hline & $\mathbf{N}$ & Mean Rank & Sum of Rank \\
\hline Negative Ranks & $0^{\mathrm{a}}$ & 0,00 & 0,00 \\
Positive Ranks & $20^{\mathrm{b}}$ & 10,50 & 210,00 \\
Ties & $0^{\mathrm{c}}$ & & \\
Total & 20 & & \\
Z & $-3.923^{\mathrm{a}}$ & & \\
Asymp. & 0,000 & & \\
Sig. (2-tailed) & 0,000 & & \\
\hline
\end{tabular}

Berdasarkan hasil uji Wilcoxon yang telah dilakukan dengan $\mathrm{N}=20$ didapatkan nilai negative ranks $=0$ yang berarti tidak ada subjek penelitian yang mengalami penurunan kecepatan berjalan dari penggunaan rigid medial arch support ke flexible medial arch support. Sedangkan nilai positive ranks $=20$, yang berarti bahwa semua subjek penelitian mengalami peningkatan kecepatan berjalan dari penggunaan rigid medial arch support ke flexible medial arch support. Selain itu didapatkan nilai ties $=$ 0 , yang berarti tidak ada subjek penelitian yang kecepatan berjalan dengan menggunakan rigid medial arch support dan flexible medial arch support memiliki nilai yang sama.

Jika dilihat berdasarkan hasil analisis statistik dengan menggunakan uji wilcoxon yang telah dilakukan, maka didapatkan nilai $\mathrm{P}=0,000(\mathrm{P}<0,05)$, maka hal tersebut dapat menjawab adanya perbedaan kecepatan berjalan penggunaan rigid medial arch support dengan flexible medial arch support pada penderita flat foot. Ho ditolak dan Ha diterima.

\section{PEMBAHASAN}

Dari hasil uji statistik yang telah dilakukan maka didapatkan nilai $\mathrm{P}=0.000$ $(\mathrm{P}<0.05)$ dimana hasilnya menunjukkan bahwa secara statistik menyatakan bahwa terdapat perbedaan signifikan pada kecepatan berjalan menggunakan rigid medial arch support dengan kecepatan berjalan menggunakan flexible medial arch support. Kecepatan berjalan penderita flat foot lebih cepat ketika menggunakan flexible medial arch support dibandingkan ketika menggunakan rigid medial arch support. Jika dilakukan pengkajian dari gait analysis subjek penelitian pada saat berjalan, pemakaian flexible medial arch support lebih fleksibel dan mampu menyesuaikan pergerakan foot sehingga fase berjalan dari heel strike sampai heel strike lagi dapat dilalui dengan baik dan fase toe off dapat dilalui tanpa adanya hambatan terutama pada bagian metatarsophalangeal joint.

Hasil ini sesuai dengan yang disampaikan oleh Siswiyanti et all (2013) bahwa pemilihan penggunaan medial arch support dengan bahan yang lentur dapat digunakan untuk menyangga arkus tetap terjaga. Pada bagian heel pad akan meredam atau mengurangi daya tekan pada bagian heel. Tekanan plantar foot akan didistribusikan ke bagian arch support, metatarsal shaft, heel, hingga pada bagian forefoot. Secara biomekanik, bagian medial wedge pada medial arch support akan menahan beban kaki terutama bagian mid foot (tengah kaki) sehingga dapat mencegah terjadinya pronasi kaki yang membuat keseimbangan akan terganggu. Sedangkan pemakaian rigid medial arch support lebih kaku dan 
kurang dapat menyesuaikan pergerakan foot terutama pada bagian metatarsophalangeal joint yang kaku sehingga fase berjalan pada saat toe off tidak dapat dilalui dengan baik.

Dari segi bahan penggunaan bahan yang rigid atau kaku baik digunakan untuk koreksi dan untuk mengontrol pergerakan (Dutton, 2001) sehingga pergerakan foot pada saat berjalan akan sedikit terbatas. Selain itu disampaikan pula oleh Siswiyanti et all (2013) bahwa bahan plastik PE $2 \mathrm{~mm}$ sifatnya lebih rigid/kaku dan licin pada saat digunakan untuk berjalan. Maka dari itu diperlukan bahan dengan material soft yang dapat mendukung kecepatan berjalan penderita flat foot. Jika ditemukan flat foot pada anak usia 8 sampai 12 tahun, pemberian intervensi berupa flexible medial arch support dapat dipilih agar kecepatan berjalan penderita flat foot lebih cepat dan kenyamanan saat berjalan dapat dicapai. Ini sesuai dengan pernyataan yang disampaikan oleh subjek penelitian bawasannya semua subjek merasa lebih nyaman ketika berjalan menggunakan flexible medial arch support dibandingkan menggunakan rigid medial arch support.

Selain itu sesuai pula dengan teori yang disampaikan oleh Dutton (2001) bahwa bahan yang soft dapat memberikan kenyamanan dengan memberikan kontrol sendi yang terbatas ketika digunakan.

\section{KESIMPULAN}

Dari hasil penelitian yang telah dilakukan dapat disimpulkan bahwa terdapat perbedaan kecepatan berjalan penggunaan rigid medial arch support dengan flexible medial arch support pada penderita flat foot. Hal ini dikarenakan penggunaan medial arch support dengan bahan yang lentur dapat digunakan untuk menyangga arkus tetap terjaga. Sedangkan pemakaian rigid medial arch support lebih kaku dan kurang dapat menyesuaikan pergerakan foot terutama pada saat berjalan.

\section{DAFTAR RUJUKAN}

Sahabuddin. (2016). Hubungan Antara Flat Foot Dengan Keseimbangan Dinamis Pada Murid TK Sulawesi Kota Makassar, Makassar : Program studi Fisioterapi Fakultas kedokteran Universitas Hasanuddin.

Mortazavi S.J \& Espandar R. (2007). Flat foot in Children:How to Approach. Tehran, IR Iran : Orthopedic Surgeon, Sports Medicine Research Center, University of Tehran/ Medical Sciences.

Evans J.R. and Lindsay WM. (2008). The Management and Control of Quality (7th Edition). Ohio: Thomson South-Western.

Utomo PC. Setyawan D. \& Syaifuddin M. (2017). Penyuluhan dan Deteksi Dini Kasus Flat Foot di Desa Gagaksipat, Ngemplak, Boyolali. Kementerian Kesehatan Republik Indonesia : Politeknik Kesehatan Surakarta, Jurusan Ortotik Prostetik.

Idris FH. (2010). Filogeni dan Ontogeni Lengkung Kaki Manusia, Jakarta : Departemen Kedokteran Fisik dan Rehabilitasi Medik, Fakultas Kedokteran Universitas Indonesia/ Rumah Sakit Dr. Cipto Mangunkusumo.

Lutfie SH. (2007). Hubungan antara Derajat Lengkung Kaki dengan 
Tingkat Kemampuan Endurans pada Calon Jamaah Haji. Jakarta : Fakultas Kedokteran dan Ilmu Kesehatan, UIN (Universitas Negeri Islam) Syarif Hidayatullah.

Santoso D. (2011). Perawatan Tepat Bagi Anda yang Memiliki Telapak Kaki Datar (Flat Feet), Sport Injuries \& Rehabilitation,(Online),(http://dunia fitn es.com/sport-injuriesrehabilitation/perawatan-tepatbagi-anda-yang- memiliki-telapakkaki-datar-flat-feet.html

Siswiyanti et al. (2013). Pengaruh Pemberian Edukasi Dan Medial Arch Support Terhadap Keseimbangan Dinamis Pada Kondisi Fleksibel Flatt Footanak Usia 8 S/D 10 Tahun. Jurnal Ilmu Kesehatan : vol 2 (2) : 41-155.

Dutton M. (2011). Physical Therapist Assistant Exam Review Guide; Pennsylvania : Second Edition, Jonnes \& Bartlett Publishers. 